\title{
Multi-Year Assessment of Airborne Metals in Fallon, Nevada, using Leaf-Surface Chemistry
}

\author{
Paul R. Sheppard ${ }^{1}$, Gary Ridenour ${ }^{2}$ and Mark L. Witten ${ }^{3}$ \\ ${ }^{1}$ Laboratory of Tree-Ring Research, University of Arizona, Tucson, Arizona 85721 \\ 2625 W. Williams Ave., Suite B, Fallon, Nevada 89406 \\ ${ }^{3}$ Odyssey Research Institute, Tucson, Arizona, 85710
}

USA

\section{Introduction}

\subsection{Fallon, Nevada}

Spatial patterns of airborne metals are described from leaf-surface chemistry of trees in Fallon, Nevada (Fig. 1a), where a cluster of childhood leukemia began in 1997. Officially, 16 cases of childhood leukemia were diagnosed from 1997 to 2002 inclusive (Expert Panel, 2004), and one additional case was reported in December 2004 (Nevada State Health Division, 2004). Although the cluster is thought to have abated (Reno Gazette-Journal, 11 October 2008), at least one additional case of childhood leukemia has occurred in Fallon since 2004 (Lahontan Valley News, 15 October 2010). Given Fallon's pediatric population of about 2500 children up to 19 years in age (U.S. Census, 2000) and a national expected rate of childhood leukemia of 4.1 cases per 100,000 children up to 19 years in age per year (U.S. NCI, 2003), the expected rate of childhood leukemia for Fallon should be only one case every ten years.

This cluster, deemed "one of the most unique ever reported" (Steinmaus et al., 2004; Steinmaus et al., 2005), prompted multiple investigations to determine if an environmental cause might have been responsible. Research focused on drinking water (Moore et al. 2002; Shaw et al., 2005; Walker \& Fosbury 2009; Walker et al., 2006), jet fuel (U.S. ATSDR, 2002), pesticides (Rubin et al., 2007; U.S. CDC, 2003), surface water (U.S. ATSDR, 2003a), outdoor air (U.S. ATSDR, 2003b), surface soil and indoor dust (U.S. ATSDR, 2003c), potential lingering effects of underground nuclear bomb testing in the area (Seiler, 2004), and groundwater (Seiler et al., 2005). A non-environmental hypothesis-population mixing-was also considered (Kinlen \& Doll, 2004; Wakeford, 2004]. Few definitive conclusions emerged from these studies, prompting an interpretation that Fallon had been given a "clean bill of health" by the US Agency for Toxic Substances and Disease Registry and the US Centers for Disease Control (Lahontan Valley News, 8 August 2007). However, this interpretation is questionable (Pleil et al., in press), and the need to monitor the environment of Fallon continues to exist.

To monitor the environment of Fallon, we have employed multiple techniques, all of which have shown notable patterns of airborne tungsten and cobalt. Elevated tungsten and cobalt was identified in airborne particulates of Fallon relative to comparison towns (Sheppard et al., 2006a) and in lichens within Fallon compared to outlying desert areas (Sheppard et al., 
2007b). Tungsten and cobalt maxima were found in surface dust (fallout from air) near the center of Fallon, just north and west of the crossroads of the main highways (Sheppard et al., 2007a). Dendrochemistry showed that tungsten began increasing in Fallon tree rings by the mid-1990s, coinciding roughly with the onset of the cluster of childhood leukemia (Sheppard et al., 2007c). From direct microscopy analysis of airborne tungsten particles in Fallon, they are anthropogenic in origin, not natural (Sheppard et al., 2007d).

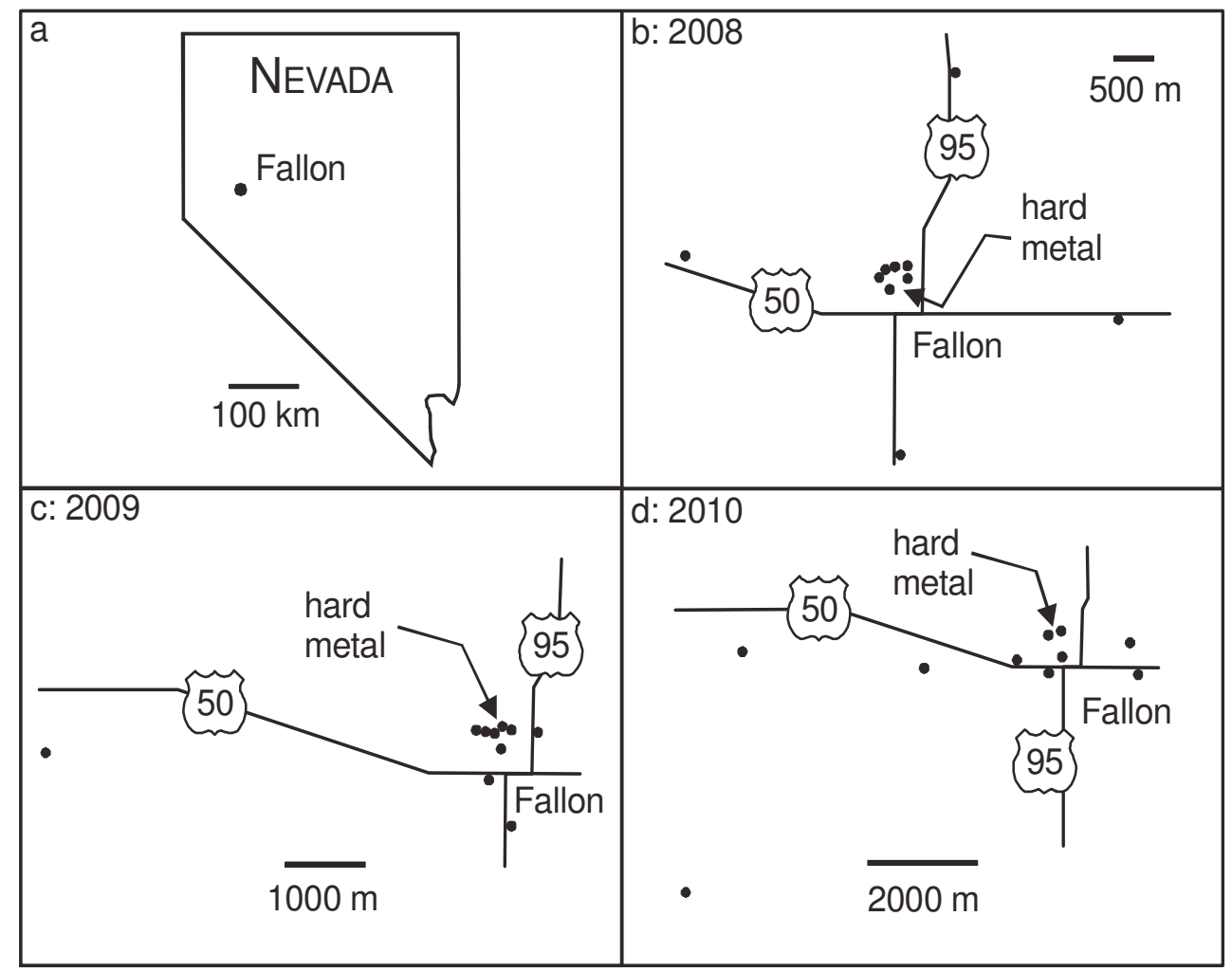

Fig. 1. Maps of Nevada, showing Fallon (a) and of Fallon, showing trees from which leaves were collected each year from 2008 through 2010 (b-d). An industrial facility performing hardmetal metalurgy is located just northwest of the main intersection of Highways 95 and 50.

\subsection{Leaf-surface chemistry to assess air quality}

An environmental monitoring technique that is applicable for assessing air quality is leafsurface chemistry, the measurement and interpretation of element concentrations in particulates that accumulate on surfaces of leaves of trees and other plants. Leaf-surface chemistry indicates atmospheric chemistry (Wittig, 1993), including airborne metals (Rautio et al., 1998). Leaves are easy to collect (Aksoy et al., 1999), so spatial and temporal arrays of samples can be obtained quickly (Loppi et al., 1997). Leaf-surface particulates reflect the chemical composition of recent accumulations, on the order of weeks to months or perhaps an entire growing season depending on the occurrence of precipitation (Alfani et al., 1996b). 
By collecting leaves across a region, differing accumulations of airborne metals can be mapped, thereby pinpointing source areas (Aboal et al., 2004). Paired studies of leaf-surface accumulations with ground-surface dust and/or airborne particulates can be particularly fruitful for confirming airborne chemistry and identifying spatial patterns of metals (Bargagli 1993; Čeburnis and Steinnes 2000). Because of these advantages, many case studies exist worldwide using leaf-surface chemistry to quantify atmospheric loading of heavy metals and/or identify their spatial patterns (e.g., Aksoy and Öztürk, 1997; Aksoy et al., 1999; Alfani et al., 1996a; Dasch, 1987; Gupta et al., 2004; Rossini Oliva and Mingorance, 2006; Salve et al., 2006; Ward, 1977;). More specifically, leaf-surface chemistry was done in Fallon in 2007, and it showed elevated peaks of airborne tungsten and cobalt just northwest of the center of town (Sheppard et al., 2009a).

\subsection{Objective}

For years now, we have been collecting various biological samples in and around Fallon for the purpose of assessing air quality there. Total suspended (airborne) particulate samples were collected in March and November 2004. Lichens and surface dust were collected in March 2005. Tree leaves were first collected in October 2007. Tree-ring samples have been collected multiple times since 2002. As time progresses, this time series of observations of air quality of Fallon becomes more and more precious by virtue of the ability to discern change in air quality through time. Therefore, it is important that regular monitoring of air quality of Fallon be maintained. A relevant Nevada state agency charged with environmental monitoring and protection has stated no plans for doing investigations in Fallon (Lahontan Valley News, 3 December 2005), but we are carrying on with environmental monitoring in Fallon.

Weighing advantages and disadvantages of various environmental monitoring techniques (Sheppard et al., 2009b), we have chosen leaf surface chemistry as the technique with which to continue monitoring Fallon air quality. Accordingly, leaves from trees of Fallon were collected in October of 2008, 2009, and 2010. The objective of this chapter is to describe the surface chemistry of these leaves to update spatial patterns of airborne tungsten and cobalt in Fallon.

\section{Methods}

\subsection{Site description}

Fallon is a small, rural, farming community (Greater Fallon Area Chamber of Commerce, 2008) located in west-central Nevada (Fig. 1a). Its climate is cool to mild and dry, with a mean annual temperature and precipitation of $10.7^{\circ} \mathrm{C}$ and $127 \mathrm{~mm}$, respectively, as typified from meteorological data from Fallon (monthly data from 1931 to 2010 obtained on-line from the National Climatic Data Center, NOAA 2010). Along with service industries and small businesses, Fallon has a facility that does hard-metal metallurgy, which includes tungsten carbide and cobalt (Harris and Humphreys, 1983). The hard-metal facility has been considered a candidate source of tungsten within Fallon generally (Reno Gazette-Journal, 5 February 2003) and more specifically of elevated tungsten and cobalt in total suspended particulates and in surface dust of Fallon (Sheppard et al., 2006a, 2007a).

\subsection{Leaf collection}

Tree leaves were collected in mid- to late-October of the years 2008, 2009, and 2010. All trees sampled were deciduous species, so results of this study reflect accumulations of airborne particulates onto leaf surfaces during just the growing season of each year. During the leaf 
season (May-October) of all four years 2007-2010, measurable rainfall was recorded in varying amounts at the nearby Fallon Naval Air Station (Fig. 2; daily data obtained on-line from the National Climatic Data Center, NOAA 2010).

All trees sampled were broadleaf species, in part because conifer species are not common in Fallon but also because broad leaves provide ample surface for accumulating airborne particulates. Tree species was not held constant during collecting because no single species predominates throughout all parts of Fallon. The urban forest of Fallon contains many kinds of trees, and elm (Ulmus), mulberry (Morus), cottonwood (Populus), and ash (Fraxinus) were the most common tree types sampled. Accumulation of aerosols onto leaves can be affected by leaf characteristics such as roughness, pubescence, moisture, and stickiness (Wedding et al., 1977), but these characteristics of leaves do not vary appreciably across the tree species sampled in this study.

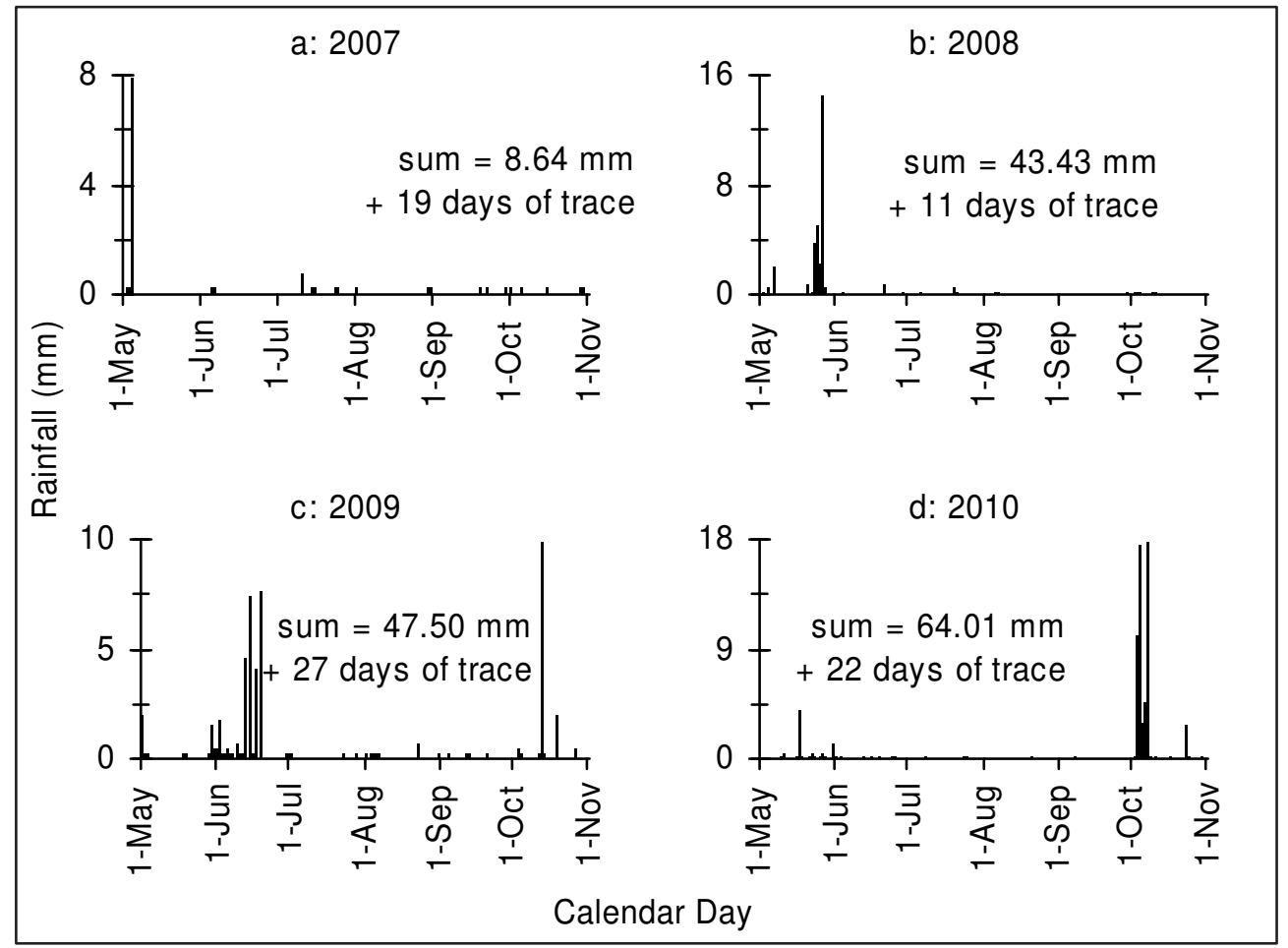

Fig. 2. Daily rainfall in Fallon during May through October for each year of leaf collection, 2007 through 2010. Short marks indicate days with only a trace of rainfall $(<0.25 \mathrm{~mm})$. Data from NCDC, NOAA. Graph for 2007 is modfied from Sheppard et al. (2009a).

Trees were selected for sampling at differing spatial densities from one year to the next. In 2008 and 2009, some trees were sampled within $0.25 \mathrm{~km}$ of the hard-metal facility, i.e., very near to it, while others were sampled farther away (Fig. 1b,c). In 2010, trees were sampled along a more even continuum of distance from the hard-metal facility (Fig. 1d). Sampling near the hard-metal facility does not represent biased sampling on our part, as has been suggested by others (Sueker, 2006). Rather, this is an example of targeted sampling (e.g., 
Seinfeld, 1972) to take advantage of prior knowledge that the area of the hard-metal facility is known to be where peak loadings of airborne tungsten and cobalt have occurred and where spatial variability in airborne tungsten and cobalt has been high (Sheppard et al., 2006b). In each year 2008-2010, leaves from just 10 trees were sampled, as opposed to the 95 trees sampled in 2007 (Sheppard et al., 2009a). It is no longer necessary to sample extremely intensively to discern patterns of airborne tungsten and cobalt in Fallon. Geographic coordinates were recorded for each sampled tree to facilitate mapping.

From each tree sampled, an outer branchlet of several leaves was clipped off with pruning cutters from a height of about $2 \mathrm{~m}$ above ground. The aspect of each tree sampled was not held constant or patterned, so sampling was effectively random across trees. None of the trees sampled was next to other trees, so there is no forest canopy effect in this study (Dasch, 1987). Branchlets were stored in clean paper bags during fieldwork. Later, leaves were trimmed from their petioles using clean, ceramic (non-metal) scissors.

\subsection{Chemical measurement}

Leaf tissues themselves were not measured for metals content, but rather rinse water solutions of particulates from the leaf surfaces were measured. Consequently, this study reflects airborne metals that accumulate on leaf surfaces, not soil-derived metals that move through the trees to leaf tissues (Wolterbeek and Bode, 1995). Trimmed leaves were placed in clean, 50-ml polypropylene vials, and tepid, de-ionized water was added to completely submerge the leaves. The vials were capped tightly and shaken lightly for two hours (Little, 1973). Rinse solutions were poured into new, clean polyurethane vials. Rinsed leaves were then oven dried at $50^{\circ} \mathrm{C}$ for several days and weighed to $\pm 0.0001 \mathrm{~g}$.

Rinse solutions were filtered with acid-washed GHP Acrodisc syringe filters (less than 0.2 $\mu \mathrm{m})$ and acidified to $\mathrm{pH}$ less than 2 with certified pure nitric acid. Measurement was performed using inductively coupled plasma, mass spectroscopy ICP-MS (Elan DRC-II, Perkin Elmer, Shelton, CT). Most analytes were measured in standard mode (e.g., vanadium, nickel, copper, zinc, arsenic, cadmium, cesium, tungsten, lead, and uranium), while chromium and cobalt were measured using the dynamic reaction cell (DRC) flushed with ammonia gas. For all elements measured, detection limits were sub-ppb based on three standard deviations from the mean of 11 replicate measurements.

\subsection{Quantitative analysis}

Measured contents of metals in rinse solutions were standardized to oven dry mass of leaves measured. Oven dry leaf masses were first transformed to the $3 / 4$ power before this standardization step. This transformation incorporates a concept of diminishing returns whereby leaf area increases ever more slowly as leaf mass increases, i.e., at a power of $3 / 4$ of leaf mass (Niklas \& Cobb, 2008). This transformation was not done originally with the 2007 leaf collection (Sheppard et al., 2009a), but it has since been done on that data set in addition to the data from 2008-2010.

The 2008 and 2009 collections were analyzed by testing medians of element concentrations from trees near the hard-metal facility versus trees away from it. The Mann-Whitney test of medians (Sokal \& Rohlf, 1981) was used to assess significance between near trees versus far trees, with the alternative hypothesis being one-tailed, i.e., that element concentrations of trees near the hard-metal facility were higher than those of trees farther away. The 2010 collection was analyzed by plotting concentration values by distance from the hard-metal facility and assessing the strength of a power function model for each element. 


\section{Results}

\subsection{Year 2008}

From leaves of 2008, tungsten and cobalt show the largest differences between trees near the hard-metal facility versus trees away from it. Tungsten and cobalt medians were 38 times and 16 times more concentrated on surfaces of leaves of trees near the facility than trees far away (Table 1). These differences are highly significant.

\begin{tabular}{|c|c|c|c|c|}
\hline \multirow[b]{2}{*}{ element } & \multicolumn{2}{|c|}{ Concentration $\left(\mu \mathrm{g} \cdot \mathrm{g}^{-(3 / 4)}\right)$} & \multirow[b]{2}{*}{$\begin{array}{c}\text { Near: } \\
\text { Far }\end{array}$} & \multirow[b]{2}{*}{$\mathrm{p}$ value } \\
\hline & $\begin{array}{l}\text { Near } \\
(\mathrm{n}=6)\end{array}$ & $\begin{array}{c}\text { Far } \\
(\mathrm{n}=4)\end{array}$ & & \\
\hline tungsten & 0.793 & 0.021 & 37.76 & 0.007 \\
\hline cobalt & 2.052 & 0.131 & 15.66 & 0.007 \\
\hline nickle & 0.526 & 0.040 & 13.15 & 0.021 \\
\hline cesium & 0.045 & 0.004 & 11.25 & 0.021 \\
\hline sodium & 3934 & 406 & 9.69 & 0.035 \\
\hline tantalum & 0.0045 & 0.0005 & 9.00 & 0.007 \\
\hline rubidium & 7.53 & 0.94 & 8.01 & 0.021 \\
\hline magnesium & 2603 & 329 & 7.91 & 0.055 \\
\hline zirconium & 0.051 & 0.011 & 4.64 & 0.007 \\
\hline lead & 0.037 & 0.008 & 4.63 & 0.013 \\
\hline silicon & 331 & 87 & 3.80 & 0.035 \\
\hline beryllium & 0.0018 & 0.0005 & 3.60 & 0.143 \\
\hline copper & 0.596 & 0.187 & 3.19 & 0.055 \\
\hline phosphorus & 631 & 218 & 2.89 & 0.120 \\
\hline titanium & 2.18 & 0.78 & 2.79 & 0.083 \\
\hline molybdenum & 0.086 & 0.032 & 2.69 & 0.035 \\
\hline vanadium & 0.067 & 0.028 & 2.39 & 0.007 \\
\hline strontium & 18.0 & 7.7 & 2.34 & 0.169 \\
\hline zinc & 3.00 & 1.32 & 2.27 & 0.013 \\
\hline potassium & 17229 & 7715 & 2.23 & 0.083 \\
\hline chromium & 0.021 & 0.010 & 2.10 & 0.035 \\
\hline gallium & 0.036 & 0.018 & 2.00 & 0.228 \\
\hline barium & 1.26 & 0.76 & 1.66 & 0.228 \\
\hline lithium & 14.9 & 10.3 & 1.45 & 0.457 \\
\hline calcium & 5063 & 3554 & 1.42 & 0.169 \\
\hline arsenic & 0.188 & 0.157 & 1.20 & 0.375 \\
\hline aluminum & 8.7 & 10.6 & 0.82 & $\varnothing$ \\
\hline barium & 264 & 410 & 0.64 & $\varnothing$ \\
\hline manganese & 37 & 207 & 0.18 & $\varnothing$ \\
\hline selenium & 0.001 & 0.027 & 0.04 & $\varnothing$ \\
\hline iron & 18 & 563 & 0.03 & $\varnothing$ \\
\hline
\end{tabular}

Table 1. Results for the 2008 collection, sorted by the ratio Near:Far, i.e., the ratio of the median value of trees near the hard-metal facility versus trees farther away from it. Concentration values are medians. P value is for Mann-Whitney testing of no difference between median values versus the one-tailed alternative that the near median is greater than the far median (Sokal \& Rohlf, 1981). 
Other elements measured show smaller differences between trees near the hard-metal facility versus trees away from it. Most elements show near:far ratios of less than 10, and most of these differences are less significant statistically than the differences for tungsten and cobalt (Table 1). Of these other elements, nickel and cesium show the highest near:far ratios, both above 10. Cesium showed notable spatial variability in the 2007 collection (Sheppard et al., 2009a), and this replication of spatial variability in cesium makes that element potentially interesting environmentally in Fallon.

\subsection{Year 2009}

From leaves of 2009, tungsten and cobalt show the largest differences between trees near the hard-metal facility versus trees away from it. Tungsten and cobalt medians were 12 times and 7 times more concentrated on surfaces of leaves of trees near the facility than trees far away (Table 2). These differences are highly significant.

Other elements measured show smaller differences between trees near the hard-metal facility versus trees away from it. Other elements show near:far ratios of 3.0 or less, and most of these differences are less significant statistically than the differences for tungsten and cobalt (Table 2). No other element measured shows spatial variability that is especially notable or potentially interesting environmentally in Fallon.

\subsection{Year 2010}

From leaves of 2010, the negative power model of tungsten concentration as a function of distance from the hard-metal facility is very strong. The $\mathrm{R}^{2}$ value of the tungsten model is $62 \%$ (Fig. 3a), much higher than other elements (Fig. 3b-i). The negative power model of cobalt concentration as a function of distance from the hard-metal facility is weaker but still notable. The $\mathrm{R}^{2}$ value of the cobalt model is $12 \%$, though that is without an obvious high outlying value from the tree that was nine $\mathrm{km}$ away from the facility (Fig. 3b).

\begin{tabular}{|c|c|c|c|c|}
\hline \multirow[b]{2}{*}{ element } & \multicolumn{2}{|c|}{ Concentration $\left(\mu \mathrm{g} \cdot \mathrm{g}^{(-3 / 4)}\right)$} & \multirow[b]{2}{*}{$\begin{array}{l}\text { Near: } \\
\text { Far }\end{array}$} & \multirow[b]{2}{*}{$\underset{\text { value }}{\mathrm{p}}$} \\
\hline & $\begin{array}{l}\text { Near } \\
(\mathrm{n}=4)\end{array}$ & $\begin{array}{c}\text { Far } \\
(\mathrm{n}=6)\end{array}$ & & \\
\hline tungsten & 0.176 & 0.015 & 11.73 & 0.007 \\
\hline cobalt & 0.757 & 0.113 & 6.70 & 0.007 \\
\hline selenium & 0.015 & 0.005 & 3.00 & 0.055 \\
\hline calcium & 1329 & 507 & 2.62 & 0.120 \\
\hline iron & 1.760 & 0.924 & 1.90 & 0.120 \\
\hline chromium & 0.009 & 0.005 & 1.80 & 0.083 \\
\hline potassium & 2814 & 1945 & 1.45 & 0.297 \\
\hline
\end{tabular}

Table 2. Results for the 2009 collection, sorted by the ratio Near:Far, i.e., the ratio of the median value of trees near the hard-metal facility versus trees farther away from it. Concentration values are medians. $P$ value is for Mann-Whitney testing of no difference between median values versus the one-tailed alternative that the near median is greater than the far median (Sokal \& Rohlf, 1981). 


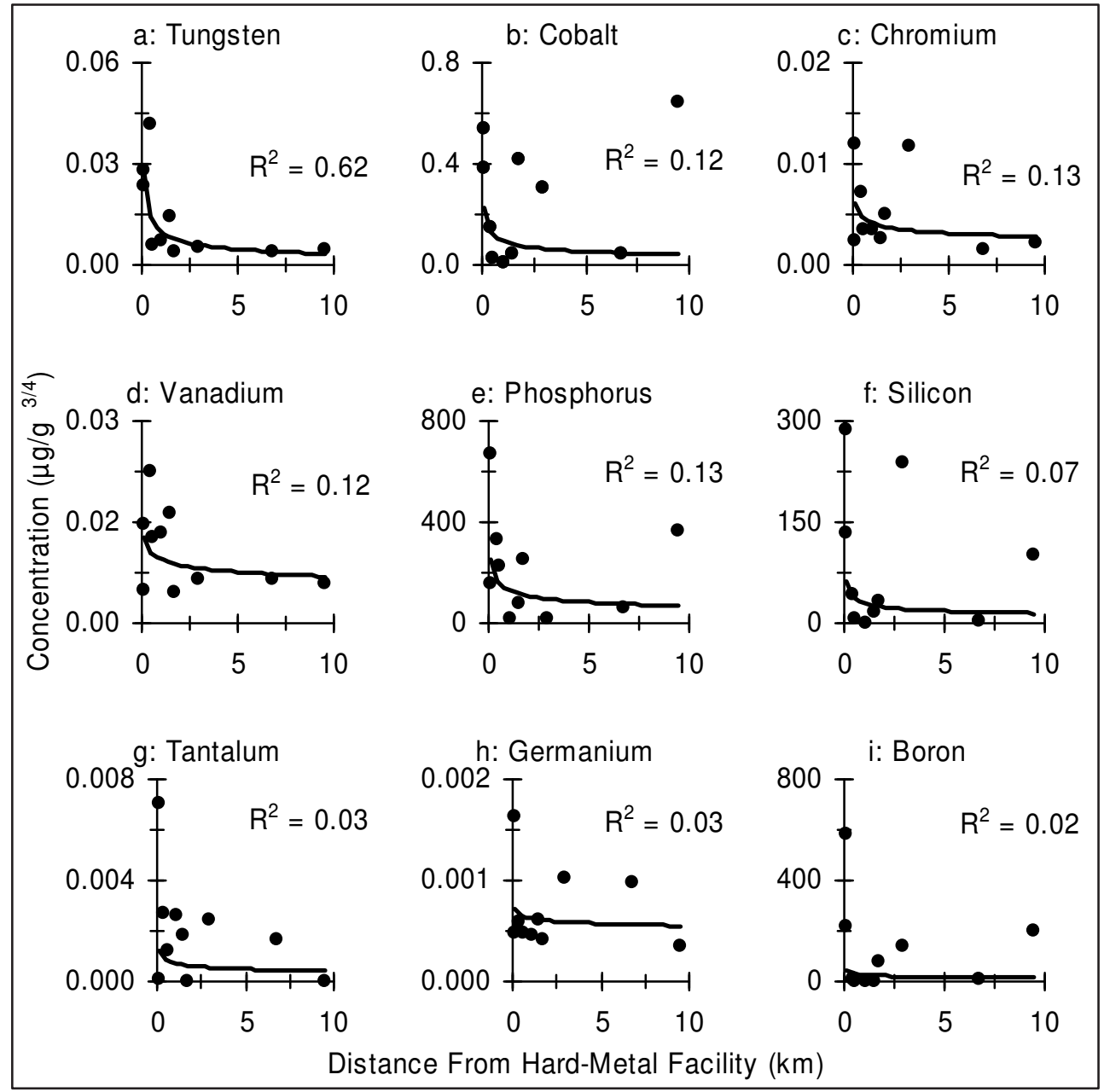

Fig. 3. Leaf surface concentration (mass of element per oven dry mass of leaf raised to the $3 / 4$ power) of elements as a function of distance from the hard-metal facility $(\mathrm{km})$ for the 2010 collection. The $\mathrm{R}^{2}$ value for cobalt is without the outlying value included.

The negative power models of other elements measured are weaker than that of tungsten. Chromium, vanadium, and phosphorus have $\mathrm{R}^{2}$ values about as strong as that of cobalt (Fig. 3c-e), while other elements have very weak $\mathrm{R}^{2}$ values (Fig. 3f-i).

\subsection{Years 2007-2010}

A temporal pattern in absolute maximum values emerged for elements that have been measured all four years. Maximum concentrations of tungsten, cobalt, and chromium have declined fairly steadily from 2007 through 2010 (Table 3). A possible explanation of this trend is that total summer rainfall for Fallon has steadily increased from 2007 through 2010 (Table 3). Maximum concentrations of these three elements show clear negative 
relationships with total summer rainfall, each with strong $\mathrm{R}^{2}$ values (Fig. 4). Rainfall has the obvious potential effect of cleaning leaf surfaces of dust that leaves catch throughout the growing season.

\section{Discussion}

This work confirms various advantages of leaf-surface chemistry as a technique for assessing air quality. As a relatively easy and inexpensive method, many leaf samples can be collected and analyzed, either for fine-turning spatial variability of air quality at one point in time (Sheppard et al., 2009a) or for assessing temporal variability of air-quality for one area (this study).

\begin{tabular}{|c|c|c|c|c|}
\hline \multirow[b]{2}{*}{ Year } & \multicolumn{3}{|c|}{ Maximum Concentration $\left(\mu \mathrm{g} \cdot \mathrm{g}^{-(3 / 4)}\right)$} & \multirow{2}{*}{$\begin{array}{c}\text { Summer } \\
\text { Rainfall (mm) }\end{array}$} \\
\hline & Tungsten & Cobalt & Chromium & \\
\hline 2007 & 16.40 & 6.70 & 0.089 & 8.64 \\
\hline 2008 & 4.78 & 8.47 & 0.052 & 43.43 \\
\hline 2009 & 0.39 & 1.29 & 0.021 & 47.50 \\
\hline 2010 & 0.04 & 0.64 & 0.012 & 64.01 \\
\hline
\end{tabular}

Table 3. Maximum concentration of tungsten, colbalt, and chromium for each year of collecting leaves in Fallon, and total summer (May through October) rainfall recorded at the Fallon Naval Air Station.

Notable findings emerged from this work. One, maximum values of airborne tungsten and cobalt in Fallon have been varying through time at the annual scale. Absolute values from leaf-surface chemistry are standardized for multiple procedural sources of variation (e.g., differing solution volumes and leaf sizes), so the interannual variability in airborne tungsten and cobalt shown here is probably environmental in nature. A logical explanation for this variability is differing summer rainfall totals from year to year.

Two, even during a summer leaf season with high rainfall (i.e., $64 \mathrm{~mm}$ in 2010), which logically should reduce absolute values of airborne metals on leaf surfaces, spatial patterns of airborne elements are still discernible with leaf-surface chemistry. This illustrates the robustness of this technique for assessing air quality, at least in environments that are relatively arid to begin with.

In general, long-term environmental monitoring is extremely valuable. Multi-year assessment research allows for discovering slow changes in environmental quality (Johnston, 1991), some of which could have implications for public health. Given the temporal variability of air quality in Fallon, it seems imperative that environmental monitoring and assessment of Fallon, especially for air quality, be continued. Even without considering linkage between exposure to airborne tungsten and cobalt and human illness, merely knowing that airborne tungsten and cobalt are elevated in Fallon and that their airborne loadings are changing through time logically suggests that continuing monitoring and assessment is prudent. Leaf-surface chemistry is a suitable technique for such long-term assessment. 


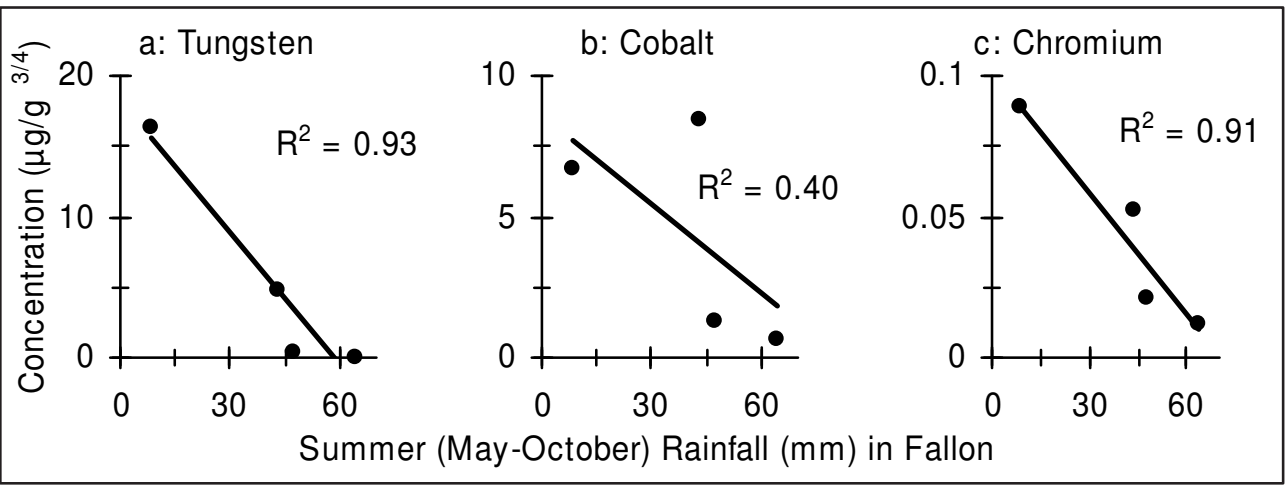

Fig. 4. Maximum concentration (mass of element per oven dry mass of leaf raised to the $3 / 4$ power) of tungsten (a), cobalt (b), and chromium (c) as a funtion of total summer (MayOctober) rainfall (mm) recorded in Fallon for each year (2007-2010).

\section{Conclusion}

Leaf-surface chemistry is an effective technique for assessing air quality, including for loadings of airborne metals and especially in urban settings. From leaf-surface chemistry, the center area of Fallon is shown to continue having elevated airborne tungsten and cobalt relative to outlying areas around Fallon. Interannual variability in absolute maximum values is notable.

It cannot be concluded from only environmental data that elevated airborne tungsten and/or cobalt cause childhood leukemia. Such a connection requires direct biomedical testing. Nonetheless, given that childhood leukemia in Fallon is the "most unique cluster ever reported" (Steinmaus et al. 2004) and that Fallon is distinctive environmentally by its elevated airborne tungsten and cobalt particulates, it stands to reason that additional biomedical research is warranted to assess the leukogenicity of airborne tungsten and cobalt (e.g., Fastje et al., 2009; Kalinich et al. 2005; Miller et al., 2001; Radcliffe et al., 2010; Steinberg et al. 2007; Sun et al. 2003).

\section{Acknowledgments}

Mary Kay Amistadi assisted in this project. ICP-MS measurements were conducted at the Arizona Laboratory for Emerging Contaminants of the University of Arizona. Coauthors on original publications of the University of Arizona research in Fallon are acknowledged. Original ecologic research by the University of Arizona was funded in part by the Cancer Research and Prevention Foundation and the Gerber Foundation, neither of which is otherwise responsible for content of this paper. This leaf-surface chemistry research was funded in part by the US Environmental Protection Agency. This article does not necessarily reflect the views of the U.S. Environmental Protection Agency and no official endorsement should be inferred. Sheppard and Witten have provided documents, data, and a declaration in Case CV03-03482, Richard Jernee et al. vs Kinder Morgan Energy et al., and CV03-05326, Floyd Sands et al. vs Kinder Morgan Energy et al., Second Judicial District 
Court of Nevada, Washoe County, which are related to the childhood leukemia cluster of Fallon. In those cases, the law firm of Dunlap and Laxalt, representing the plaintiffs, with full disclosure to all defendants and their counsel, made an unsolicited donation of $\$ 15,000$ to assist Witten and Sheppard in furthering their research, with a request that defendants provide similar donations.

\section{References}

Aboal, J.R.; Fernández, J.A. \& Carballeira, A. (2004). Oak Leaves and Pine Needles as Biomonitors of Airborne Trace Elements Pollution. Environmental and Experimental Botany, Vol. 51, No. 3, (June 2004), pp. 215-225, ISSN 0098-8472

Aksoy, A.; Hale, W.H.G. \& Dixon, J.M. (1999). Capsella bursa-pastoris (L.) Medic. as a Biomonitor of Heavy Metals. Science of the Total Environment, Vol. 226, No. 2-3, (February 1999), pp. 177-186, ISSN 0048-9697

Aksoy, A. \& Öztürk, M.A. (1997). Nerium oleander L. as a Biomonitor of Lead and Other Heavy Metal Pollution in Mediterranean Environments. Science of the Total Environment, Vol. 205, No. 2-3, (October 1997), pp. 145-150, ISSN 0048-9697

Alfani, A.; Bartoli, G.; Rutigliano, F.A.; Maisto, G. \& deSanto, A.V. (1996a). Trace Metal Biomonitoring in the Soil and the Leaves of Quercus Ilex in the Urban Area of Naples. Biological Trace Element Research, Vol. 51, No. 1, (January 1996), pp. 117-131, ISSN 0163-4984

Alfani, A.; Maisto, G.; Iovieno, P.; Rutigliano, F.A. \& Bartoli, G. (1996b). Leaf Contamination by Atmospheric Pollutants as Assessed by Elemental Analysis of Leaf Tissue, Leaf Surface Deposit and Soil. Journal of Plant Physiology, Vol. 148, No. 1-2, (April, 1996), pp. 243-248, ISSN 0176-1617

Bargagli, R. (1993). Plant Leaves and Lichens as Biomonitors of Natural or Anthropogenic Emissions of Mercury. In: Plants as Biomonitors, B. Markert, (ed.), 461-484, VCH, ISBN 3527300015, Weinheim, Germany

Čeburnis D. \& Steinnes E. (2000). Conifer Needles as Biomonitors of Atmospheric Heavy Metal Deposition: Comparison with Mosses and Precipitation, Role of the Canopy. Atmospheric Environment, Vol. 34, No. 25, (July 2000), pp. 4265-4271, ISSN 1352-2310

Dasch, J.M. (1987). Measurement of Dry Deposition to Surfaces in Deciduous and Pine Canopies. Environmental Pollution, Vol. 44, No. 4, (1987), pp. 261-277, ISSN 02697491

Expert Panel. (2004). Final Report and Recommendations to the Nevada State Health Division. Expert Panel on Childhood Leukemia in Churchill County, Nevada

Fastje, C.D.; Le, K.; Sun, N.N.; Wong, S.S.; Sheppard, P.R.; Witten, M.L. (2009). Pre-natal exposure to tungstate is associated with decreased transcriptome-expression of the putative tumor suppressor gene, DMBT1: implications for childhood leukemia. Land Contamination and Reclamation, Vol. 17, No. 1, (March 2009), pp. 169-178, ISSN 0967-0513

Greater Fallon Area Chamber of Commerce. (2008). History of Fallon. Accessed 1 March 2010, Available from: http:/ /www.fallonchamber.com 
Gupta, A.; Kumar, R.; Kumari, K.M. \& Srivastava, S.S. (2004). Atmospheric Dry Deposition to Leaf Surfaces at a Rural Site of India. Chemosphere, Vol. 55, No. 8, (May 2004), pp. 1097-1107, ISSN 0045-6535

Harris, P.M. \& Humphreys, D.S.C. (1983). Tungsten: A Review. Occasional Papers of the Institution of Mining and Metallurgy, Paper 2, Institution of Mining and Metallurgy, ISBN 0900488654, London, England

Johnston, A.E. (1991). Benefits from Long-Term Ecosystem Research. In: Long-Term Ecological Research: An International Perspective, P.G. Risser (ed.), 89-114, Wiley, ISBN 0471930059, Chichester, England

Kalinich, J.F.; Emond, C.A.; Dalton, T.K.; Mog, S.R.; Coleman, G.D.; Kordell, J.E.; Miller, A.C. \& McClain, D.E. (2005). Embedded Weapons-Grade Tungsten Alloy Shrapnel Rapidly Induces Metastatic High-Grade Rhabdomyosarcomas in F344 Rats. Environmental Health Perspectives, Vol. 113, No. 6, (June 2005), pp. 729-734, ISSN 0091-6765

Kinlen, L. \& Doll, R. (2004). Population Mixing and Childhood Leukaemia: Fallon and Other US Clusters. British Journal of Cancer, Vol. 91, No. 1, (July 2004), pp. 1-3, ISSN 00070920

Lahontan Valley News. (3 December 2005). Study Finds Higher Levels of Tungsten, Cobalt in Fallon Air

Lahontan Valley News. (8 August 2007). Study: Fallon Tungsten Particles Not Natural

Lahontan Valley News. (15 October 2010). Obituary: Halycon Marie Bice

Little, P. (1973). A Study of Heavy Metal Contamination on Leaf Surfaces. Environmental Pollution, Vol. 5, No. 3, pp. 159-172, ISSN 0269-7491

Loppi, S.; Nelli, L.; Ancora, S. \& Bargagli, R. (1997). Passive Monitoring of Trace Elements by Means of Tree Leaves, Epiphytic Lichens and Bark Substrate. Environmental Monitoring and Assessment, Vol. 45, No. 1, (March 1997), pp. 8188, ISSN 0167-6369

Miller, A.C.; Mog, S.; McKinney, L.; Luo, L.; Allen, J.; Xu, J.Q. \& Page, N. (2001). Neoplastic Transformation of Human Osteoblast Cells to the Tumorigenic Phenotype by Heavy Metal-Tungsten Alloy Particles: Induction of Toxic Effects. Carcinogenesis, Vol. 22, No. 1, (January 2001), pp. 115-125, ISSN 0143-3334

Moore, L.E.; Lu, M. \& Smith, A.H. (2002). Childhood Cancer Incidence and Arsenic Exposure in Drinking Water in Nevada. Archives of Environmental Health, vol. 57, No. 3, (May-June 2002), pp. 201-206, ISSN 0003-9896

Nevada State Health Division. (2004). New Childhood Leukemia Case Confirmed. News Release, 20 December 2004

Niklas, K.J. \& Cobb, E.D. (2008). Evidence for "Diminishing Returns" From the Scaling of Stem Diameter and Specific Leaf Area. American Journal of Botany, Vol. 95. No. 5, (May 2008), pp. 549-557, ISSN 0002-9122

NOAA. (2008). National Climatic Data Center. National Oceanic and Atmospheric Administration. Accessed 1 March 2010, Available from: http://www.ncdc.noaa. gov/oa/ncdc.html

Pleil, J.D.; Sobus, J.; Sheppard, P.R.; Ridenour, G. \& Witten, M.L. (In press). Strategies for Evaluating the Environment-Public Health Interaction of Long-Term Latency 
Disease: The Quandary of the Inconclusive Case-Control Study. Chemico-Biological Interactions, ISSN 0009-2797

Radcliffe, P.M.; Leavens, T.L.; Wagner, D.J.; Olabisi, A.O.; Struve, M.F.; Wong, B.A.; Tewksbury, E.; Chapman, G.D. \& Dorman, D.C. (2010). Pharmacokinetics of Radiolabeled Tungsten $(188 \mathrm{~W})$ in Male Sprague-Dawley Rats Following Acute Sodium Tungstate Inhalation. Inhalation Toxicology, Vol. 22, No. 1, (January 2010), pp. 69-76 ISSN 0895-8378

Rautio, P.; Huttunen, S. \& Lamppu, J. (1998). Element Concentrations in Scots Pine Needles on Radial Transects Across a Subarctic Area. Water Air and Soil Pollution, Vol. 102, No. 3-4, (March 1998), pp. 389-405, ISSN 0049-6979

Reno Gazette-Journal (Frank X. Mullen). (5 February 2003). No Pollution Controls in Tungsten Plant

Reno Gazette-Journal (Frank X. Mullen). (11 October 2008). Metal Remains at Heart of Fallon Leukemia Inquiry

Rossini Oliva, S. \& Mingorance, M.D. (2006). Assessment of Airborne Heavy Metal Pollution by Aboveground Plant Parts. Chemosphere, Vol. 65, No. 2, (October 2006), pp. 177182, ISSN 0045-6535

Rubin, C.S.; Holmes, A.K.; Belson, M.G.; Jones, R.L.; Flanders, W.D.; Kieszak, S.M.; Osterloh, J.; Luber, G.E.; Blount, B.C.; Barr, D.B.; Steinberg, K.K.; Satten, G.A.; McGeehin, M.A. \& Todd, R.L. (2007). Investigating Childhood Leukemia in Churchill County, Nevada. Environmental Health Perspectives, Vol. 115, No. 1, (January 2007), pp. 151157, ISSN 0091-6765

Salve, P.R.; Maurya, A. \& Wate, S.R. (2006). Atmospheric Dry Deposition on Leaves at an Urban Location. Bulletin of Environmental Contamination and Toxicology, Vol. 77, No. 6, (December 2006), pp. 834-837, ISSN 0007-4861

Seiler, R.L. (2004). Temporal Changes in Water Quality at a Childhood Leukemia Cluster. Ground Water, Vol. 42, No. 3, (May-June 2004), pp. 446-455, ISSN 0017-467X

Seiler, R.L.; Stollenwerk, K.G. \& Garbarino, J.R. (2005). Factors Controlling Tungsten Concentrations in Ground Water, Carson Desert, Nevada. Applied Geochemistry, Vol. 20, No. 2, (February 2005), pp. 423-441, ISSN 0883-2927

Seinfeld, J.H. (1972). Optimal Location of Pollutant Monitoring Stations in an Airshed. Atmospheric Environment, Vol. 6, No. 11, (1972), pp. 847-858, ISSN 1352-2310

Shaw, W.D.; Walker, M.; \& Benson, M. (2005). Treating and Drinking Well Water in the Presence of Health Risks from Arsenic Contamination: Results from a US Hot Spot. Risk Analysis, Vol. 25, No. 6, (December 2005), pp. 1531-1543, ISSN 02724332

Sheppard, P.R.; Hallman, C.L.; Ridenour, G. \& Witten, M.L. (2009a). Spatial Patterns of Tungsten and Cobalt on Leaf Surfaces of Trees in Fallon, Nevada. Land Contamination and Reclamation, vol. 17, No. 1, (March 2009), pp. 31-41, ISSN 09670513

Sheppard, P.R.; Ridenour, G.; Speakman, R.J. \& Witten, M.L. (2006a). Elevated Tungsten and Cobalt in Airborne Particulates in Fallon, Nevada: Possible Implications for the Childhood Leukemia Cluster. Applied Geochemistry, Vol. 21, No. 1, (January 2006), pp. 152-165, ISSN 0883-2927 
Sheppard, P.R.; Ridenour, G.; Witten, M.L. (2009b). Multiple Techniques for Researching Airborne Particulates: A Comprehensive Case Study of Fallon, Nevada. In: Airborne Particulates, M. Cheng \& W. Liu (eds.), 141-156, Nova Science Publishers, ISBN 9781606929070, New York

Sheppard, P.R.; Speakman, R.J.; Ridenour, G.; Glascock, M.D.; Farris, C. \& Witten, M.L. (2007a). Spatial Patterns of Tungsten and Cobalt in Surface Dust of Fallon, Nevada. Environmental Geochemistry and Health, Vol. 29, No. 5, (October 2007), pp. 405-412, ISSN 0269-4042

Sheppard, P.R.; Speakman, R.J.; Ridenour, G. \& Witten, M.L. (2006b). Reply to Comment on "Elevated Tungsten and Cobalt in Airborne Particulates in Fallon, Nevada: Possible Implications for the Childhood Leukemia Cluster", by Blasland, Bouck and Lee, Inc. Applied Geochemistry, Vol. 21, No. 6, (June 2006), pp. 1083-1088, ISSN 0883-2927

Sheppard, P.R.; Speakman, R.J.; Ridenour, G. \& Witten, M.L. (2007b). Using Lichen Chemistry to Assess Airborne Tungsten and Cobalt in Fallon, Nevada. Environmental Monitoring and Assessment, Vol. 130, No. 1-3, (July 2007), pp. 511-518, ISSN 0167-6369

Sheppard, P.R.; Speakman, R.J.; Ridenour, G. \& Witten, M.L. (2007c). Temporal Variability of Tungsten and Cobalt in Fallon, Nevada. Environmental Health Perspectives, Vol. 115, No. 5, (May 2007), pp. 715-719, ISSN 0091-6765

Sheppard, P.R.; Toepfer, P.; Schumacher, E.; Rhodes, K.; Ridenour, G. \& Witten, M.L. (2007d). Morphological and Chemical Characteristics of Airborne Tungsten Particles of Fallon, Nevada. Microscopy and Microanalysis, Vol. 13, No. 4, (August 2007), pp. 296-303, ISSN 1431-9276

Sokal, R.R. \& Rohlf, F.J. (1981). Biometry. WH Freeman and Co., ISBN 0716712547, San Francisco, California

Steinberg, K.K.; Relling, M.V.; Gallagher, M.L.; Greene, C.N.; Rubin, C.S.; French, D.; Holmes, A.K.; Carroll, W.L.; Koontz, D.A.; Sampson, E.J. \& Satten, G.A. (2007). Genetic Studies of a Cluster of Acute Lymphoblastic Leukemia Cases in Churchill County, Nevada. Environmental Health Perspectives, Vol. 115, No. 1, (January 2007), pp. 158-164, ISSN 0091-6765

Steinmaus, C.; Lu, M.; Todd, R.L. \& Smith, A.H. (2004). Probability Estimates for the Unique Childhood Leukemia Cluster in Fallon, Nevada, and Risks Near Other U.S. Military Aviation Facilities. Environmental Health Perspectives, Vol. 112, No. 6, (May 2004), pp. 766-771, ISSN 0091-6765

Steinmaus, C. \& Smith, A.H. (2005). The Highly Unusual Cluster of Childhood Leukaemia in Churchill County, Nevada. Epidemiology, Vol. 16, No. 5, (September 2005), pp. S51S51, 1044-3983

Sueker, J.K. (2006). Comment on "Elevated Tungsten and Cobalt in Airborne Particulates in Fallon, Nevada: Possible Implications for the Childhood Leukemia Cluster" by P.R. Sheppard, G. Ridenour, R.J. Speakman and M.L. Witten. Applied Geochemistry, Vol. 21, No. 6, (June 2006), pp. 1083-1085, ISSN 0883-2927

Sun, N.N.; Fastje, C.D.; Wong, S.S.; Sheppard, P.R.; Ridenour, G.; Hyde, J.D.; Macdonald, S. \& Witten, M.L. (2003). Dose-Dependent Transcriptome Changes by Metal Ores on a 
Human Acute Lymphoblastic Leukemia Cell Line. Toxicology and Industrial Health, Vol. 19, No. 7-10, (2003), pp. 157-163, ISSN 0748-2337

U.S. ATSDR. (2002). Evaluation of Potential Exposures from the Fallon JP-8 Fuel Pipeline. Agency for Toxic Substances and Disease Registry, Accessed 1 March 2010, Available from http:/ / www.atsdr.cdc.gov/HAC/pha/PHA.asp?docid=952\&pg=0

U.S. ATSDR. (2003a). Surface Water, Sediment, and Biota Human Exposure Pathway Analysis for Churchill County: Fallon Leukemia Project, Fallon, Churchill County, Nevada. Agency for Toxic Substances and Disease Registry, Accessed 1 March 2010, Available from http://www.atsdr.cdc.gov/HAC/pha/fallonwater/finalwater.pdf

U.S. ATSDR. (2003b). Air Exposure Pathway and Assessment: Fallon Leukemia Cluster Investigation. Agency for Toxic Substances and Disease Registry, Accessed 1 March 2010, Available from http://www.atsdr.cdc.gov/HAC/PHA/fallonair/finalair.pdf

U.S. ATSDR. (2003c). Pathway Assessment for Churchill County Surface Soils and Residential Indoor Dust: Fallon Leukemia Project, Fallon, Churchill County, Nevada. Agency for Toxic Substances and Disease Registry, Accessed 1 March 2010, Available from http://www.atsdr.cdc.gov/HAC/pha/fallonsoil/finalsoil.pdf

U.S. CDC. (2003). A Cross-Sectional Exposure Assessment of Environmental Exposures in Churchill County, Nevada. Centers for Disease Control and Prevention, Accessed 1 March 2010, Available from http://www.cdc.gov/nceh/clusters/fallon

U.S. Census. (2000). United States Census 2000. Accessed 1 March 2010, Available from http://www.census.gov/main/www/cen2000.html

U.S. NCI. (2003). Age-Adjusted SEER Incidence and the U.S. Death Rates and 5-Year Relative Survival Rates by Primary Cancer Sites, Sex, and Time Period. SEER Cancer Statistics Review, 1975-2000, Table XXVII-3: Childhood Cancers, U.S. National Cancer Institute. Accessed 1 March 2010, Available from http:// www.seer.cancer.gov

Wakeford, R. (2004). Extreme Childhood Leukaemia Cluster at Fallon, Nevada. Journal of Radiological Protection, Vol. 24, No. 2, (June 2004), pp. 183-184, ISSN 09524746

Walker, M. \& Fosbury, D. (2009). Arsenic, As(III), and Tungsten in Nevada County's Private Water Supplies. Journal of Water and Health, Vol. 7, No. 2, (June 2009), pp. 293-301, ISSN 1477-8920

Walker, M.; Shaw, W.D. \& Benson, M. (2006). Arsenic Consumption and Health Risk Perceptions in a Rural Western US Area. Journal of the American Water Resources Association, Vol. 42, No. 5, (October 2005), pp. 1363-1370, ISSN 1093$474 \mathrm{X}$

Ward, N.I.; Brooks, R.R. \& Roberts, E. (1977). Silver in Soils, Stream Sediments, Waters and Vegetation Near a Silver Mine and Treatment Plant at Maratoto, New Zealand. Environmental Pollution, 13, No. 4, (August 1977), pp. 269-280, ISSN 0269-7491

Wedding, J.B.; Carlson, R.W.; Stukel, J.J. \& Bazzaz, F.A. (1977). Aerosol Deposition on Plant Leaves. Water Air and Soil Pollution, Vol. 7, No. 4, (1977), pp. 545-550, ISSN 00496979 
Wittig, R. (1993). General aspects of biomonitoring heavy metals by plants. In: Plants as Biomonitors, B. Markert, (ed.), 3-27, VCH, ISBN 3527300015, Weinheim, Germany

Wolterbeek, H.T. \& Bode, P. (1995). Strategies in Sampling and Sample Handling in the Context of Large-Scale Plant Biomonitoring Surveys of Trace Element Air Pollution. Science of the Total Environment, Vol. 176, No. 1-3, (December 1995), pp. 33-43, ISSN 0048-9697 


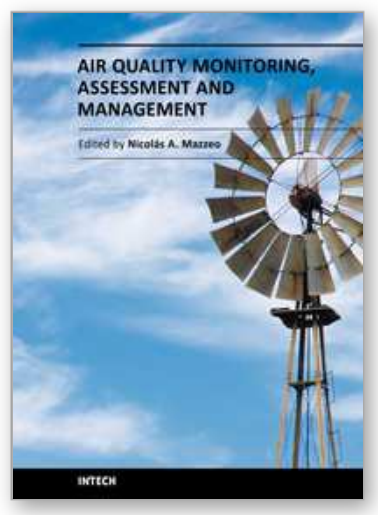

\author{
Air Quality Monitoring, Assessment and Management \\ Edited by Dr. Nicolas Mazzeo
}

ISBN 978-953-307-317-0

Hard cover, 378 pages

Publisher InTech

Published online 08, July, 2011

Published in print edition July, 2011

Human beings need to breathe oxygen diluted in certain quantity of inert gas for living. In the atmosphere, there is a gas mixture of, mainly, oxygen and nitrogen, in appropriate proportions. However, the air also contains other gases, vapours and aerosols that humans incorporate when breathing and whose composition and concentration vary spatially. Some of these are physiologically inert. Air pollution has become a problem of major concern in the last few decades as it has caused negative effects on human health, nature and properties. This book presents the results of research studies carried out by international researchers in seventeen chapters which can be grouped into two main sections: a) air quality monitoring and b) air quality assessment and management, and serves as a source of material for all those involved in the field, whether as a student, scientific researcher, industrialist, consultant, or government agency with responsibility in this area.

\title{
How to reference
}

In order to correctly reference this scholarly work, feel free to copy and paste the following:

Gary Ridenour, Mark Witten and Paul Sheppard (2011). Multi-year Assessment of Airborne Metals in Fallon, Nevada, Using Leaf-surface Chemistry, Air Quality Monitoring, Assessment and Management, Dr. Nicolas Mazzeo (Ed.), ISBN: 978-953-307-317-0, InTech, Available from: http://www.intechopen.com/books/air-qualitymonitoring-assessment-and-management/multi-year-assessment-of-airborne-metals-in-fallon-nevada-usingleaf-surface-chemistry

\section{INTECH}

open science | open minds

\section{InTech Europe}

University Campus STeP Ri

Slavka Krautzeka 83/A

51000 Rijeka, Croatia

Phone: +385 (51) 770447

Fax: +385 (51) 686166

www.intechopen.com

\section{InTech China}

Unit 405, Office Block, Hotel Equatorial Shanghai

No.65, Yan An Road (West), Shanghai, 200040, China

中国上海市延安西路65号上海国际贵都大饭店办公楼 405 单元

Phone: +86-21-62489820

Fax: $+86-21-62489821$ 
(C) 2011 The Author(s). Licensee IntechOpen. This chapter is distributed under the terms of the Creative Commons Attribution-NonCommercialShareAlike-3.0 License, which permits use, distribution and reproduction for non-commercial purposes, provided the original is properly cited and derivative works building on this content are distributed under the same license. 